\title{
Pharmacist's Practice of Reporting of Adverse Drug Reactions in Saudi Arabia
}

\author{
Fatimah Fouad Al Doughan*,1, Yousef Ahmed Alomi² (D, Mais Hasan Iflaifel ${ }^{3}$
}

${ }^{1}$ Department of Pharmacy Practice, College of Clinical Pharmacy, King Faisal University, Alahsaa, SAUDI ARABIA.

${ }^{2}$ The Former General Manager of General Administration of Pharmaceutical Care and Former Head, National Clinical Pharmacyand Pharmacy Practice and Pharmacy R and D Administration, Ministry of Health, Riyadh, SAUDI ARABIA.

${ }^{3}$ Pharmacy Practice Department, College of Clinical Pharmacy, King Faisal University, Alahsaa, SAUDI ARABIA.

\begin{abstract}
Objectives: To assess and compare the practice of reporting Adverse Drug Reactions (ADRs) and related factors between community and hospital pharmacists in Saudi Arabia. Methods: This is a cross-sectional study. We used a structured, validated questionnaire to collect the data. A total of 263 pharmacists participated in the survey. The questionnaire captures demographic data of the participants and had 26 questions related to the practice of reporting ADRs and factors that encourage and discourage pharmacists from reporting ADRs. Results: Community pharmacists did not know the location of the ADR form, but hospital pharmacists did know about it, which was significantly different $(P<0.05)$. Despite the increased awareness of ADR form among the hospital pharmacists', the overall reporting rate was found to be meager among both the group of pharmacists. We found that several reasons led to the low reporting rate of $A D R$, for example, community pharmacists were unaware of how to report ADR and they considered that the ADR is too trivial to be reported compared to hospital pharmacists $(P<0.05)$. in addition, community pharmacists were not know whom to report the ADRs compared to the hospital pharmacists, which was significantly different $(P<0.05)$. Conclusion: The results of this study demonstrated that pharmacists who work at hospitals had a higher awareness of practicing system of reporting ADRs than that of community pharmacists. Increasing awareness among community pharmacists regarding the pharmacovigilance and ADR reporting systems is highly recommended in the Kingdom of Saudi Arabia.

Key words: Pharmacist, Hospital, Community, Practice, Pharmacovigilance, Adverse drug reactions, Saudi Arabia.
\end{abstract}

Received: 17-10-2018;

Accepted: $20-12-2018$

*Correspondence to:

Dr. Fatima Fouad Al Doughan, Pharm D

Department of Pharmacy Practice, College of Clinical Pharmacy, King Faisal University, Alahsaa, SAUDI ARABIA

Phone no: +966 0504417712 Email: faldoughan369@gmail.com DOI: 10.5530/ijpcs.2019.8.15 Copyright: ๑ the author(s),publisher and licensee International Journal of Pharmacology and Clinical Sciences. This is an open-access article distributed under the terms of the Creative Commons Attribution Non-Commercial License, which permits unrestricted non-commercial use, distribution, and reproduction in any medium, provided the original work is properly cited.

This is an open access article distributed under the terms of the Creative Commons AttributionNonCommercial-ShareAlike 4.0 License

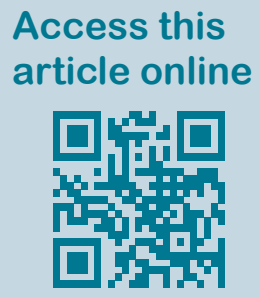

www.ijpcs.net 


\section{INTRODUCTION}

The Saudi Food and Drug Authority (SFDA) founded the National Pharmacovigilance Center (NPC) as a separate unit, which started functioning since 2009. It ensures the effective and safe use of medications and monitors the safety issues regarding medicines and their proper use. ${ }^{[1]}$ Adverse drug reactions (ADRs) need to be detected, monitored and prevented by the pharmacovigilance system as they are the common cause for increased morbidity and mortality. ${ }^{[2]}$ Patients' drug safety cannot be achieved without the collaborative efforts of the healthcare professionals (physicians, pharmacists and nurses) and patients in reporting the ADRs. ${ }^{[3]}$ Underreporting of ADRs is a global problem, including Saudi Arabia. ${ }^{[4-6]}$ Many aspects can lead to the underreporting of ADRs such as pharmacists' practice of the pharmacovigilance system. ${ }^{[7-9]}$ Therefore, in this study, we aimed to assess the practice of pharmacovigilance system and study the factors that may encourage and discourage pharmacists from reporting ADRs and compare them between the hospital and community pharmacists from different regions of Saudi Arabia.

\section{MATERIALS AND METHODS}

\section{Methods}

This is a cross-sectional study conducted from January to March 2016 in Al-Sharqyiah, Riyadh, Jeddah and another regions of Saudi Arabia. A total of 263 pharmacists (both hospital and community pharmacists) participated in this study. The questionnaire was distributed among hospital pharmacists (both public and private) and community pharmacists (chain and independent pharmacies) with the approval of health research center in eastern region. Pharmacists completed the validated, structured questionnaire and the questionnaires were delivered by hand or through the Internet, depending on the accessibility. Informed consent was obtained from all participants; the participants were informed that their information was kept confidential and that the results would be presented anonymously. The questionnaire was adapted from a previous study. ${ }^{[9]}$ It captures demographic data of the pharmacists and had 26 questions to assess the practice of reporting ADRs and factors that encourage and discourage pharmacists from reporting ADRs. Statistical analysis was performed using Statistical Package for the Social Sciences (SPSS), version 21 software. The chi-squared test for categorical variables calculated $P$ value. Mean and standard deviation (SD) were calculated for continuous variables, whereas percentage was calculated for qualitative variables.

\section{RESULTS}

In this study, a total of 263 pharmacists participated; of them, 208 (79.09\%) were from hospital pharmacy sites and 55 (20.91\%) were from community pharmacy. Most community pharmacies responded from Al-Sharqyiah (43 (78.18\%)) and most hospital pharmacies responded from Al-Riyadh (78 (37.68\%)) and Al-Sharqyiah $(73(35.27 \%))$. The number of responders were statistically significant between most of the cities $(p<0.05)$. Hospital pharmacies had statistically and significantly greater number of male population (173 $(65.78 \%))$ than that of female population, whereas community pharmacies had greater number of male population $(p<0.05)$. Most of the pharmacists participated in this study were in the age group of 24-35 years without any statistical significance between hospital and community pharmacies $(p>0.05)$. Bachelor of Science (BSc) in pharmacy was the most common educational qualification in both groups (88.89\% community pharmacist and $52.88 \%$ hospital pharmacists) without any statistical significance among all the educational qualifications $(p<0.05)$ except in the case of Ph.D where their number was more in hospital pharmacies that of community pharmacies $(p<0.05)$. However, majority of the pharmacists had $1-3$ years and more than 9 years of experience. Nine years of experience and more were more common in community pharmacists' group $(p>0.05)$, whereas hospital pharmacists had 1-3 years of experience $(p<0.05)$ (Table 1).

With regard to the availability of the ADR form, $49(89.09 \%)$ community pharmacists answered that they do not have the ADR form in their pharmacy, whereas $155(74.52 \%)$ hospital pharmacists answered a "yes" to this question. Hospital and community pharmacists (164 (83.25\%) and 21 (47.73\%), respectively) chose to fill the ADR reporting form when asked about how they would report the ADRs, whereas some of the community pharmacists $(12(27.27 \%))$ chose to verbally inform the representative of the drug company on routine visits about the ADRs. Only 7 (3.55\%) hospital pharmacists chose to verbally inform the drug company. Community pharmacists (5 (11.36\%)) chose to call the drug company to report ADRs compared to the hospital pharmacists $(5(2.54 \%))$ with a significant 


\begin{tabular}{|c|c|c|c|c|}
\hline Parameter & $\begin{array}{l}\text { Hospital } \\
\text { Pharmacy }\end{array}$ & $\begin{array}{l}\text { Community } \\
\text { Pharmacy }\end{array}$ & Total & $P$ value \\
\hline \multicolumn{5}{|l|}{ Location, N (\%) } \\
\hline Al-Ryiadh & $78(37.68)$ & $8(14.55)$ & $86(32.82)$ & $<0.05$ \\
\hline Al-Sharqyiah & $73(35.27)$ & $43(78.18)$ & $116(44.27)$ & $<0.05$ \\
\hline Jeddah & $33(15.94)$ & $2(3.64)$ & $35(13.36)$ & $<0.05$ \\
\hline Other & $23(11.11)$ & $2(3.64)$ & $25(9.54)$ & $>0.05$ \\
\hline Total & $207(79.01)$ & 55 (20.99) & $262(100)$ & \\
\hline \multicolumn{5}{|l|}{ Gender } \\
\hline [Female; N (\%)] & 89 (42.79) & $1(1.82)$ & $90(34.22)$ & $<0.05$ \\
\hline [Male; N (\%)] & $119(57.21)$ & $54(98.18)$ & $173(65.78)$ & $<0.05$ \\
\hline Total & $208(79.09)$ & $55(20.91)$ & $263(100)$ & \\
\hline \multicolumn{5}{|l|}{ Age [years] } \\
\hline $24-35$ & $153(73.91)$ & $43(78.18)$ & $196(74.81)$ & $>0.05$ \\
\hline $36-45$ & $50(24.15)$ & $11(20.00)$ & $61(23.28)$ & $>0.05$ \\
\hline $46-55$ & $4(1.93)$ & $1(1.82)$ & $5(1.91)$ & $>0.05$ \\
\hline$>55$ & $0(0.00)$ & $0(0.00)$ & $0(0.00)$ & $>0.05$ \\
\hline Total & 207 (79.01) & 55 (20.99) & $262(100)$ & \\
\hline \multicolumn{5}{|c|}{ Educational level; N (\%) } \\
\hline BSc in pharmacy & $110(52.88)$ & $48(88.89)$ & $158(60.31)$ & $<0.05$ \\
\hline PharmD & $52(25.00)$ & $3(5.56)$ & 55 (20.99) & $<0.05$ \\
\hline Masters & $40(19.23)$ & $3(5.56)$ & $43(16.41)$ & $<0.05$ \\
\hline $\mathrm{PhD}$ & $6(2.88)$ & $0(0.00)$ & $6(2.29)$ & $>0.05$ \\
\hline Total & 208 (79.39) & $54(20.61)$ & $262(100)$ & \\
\hline \multicolumn{5}{|c|}{ Years of practice [years] } \\
\hline$<1$ & $2(0.97)$ & $1(1.82)$ & $3(1.15)$ & $>0.05$ \\
\hline $1-3$ & $75(36.23)$ & $9(16.36)$ & $84(32.06)$ & $<0.05$ \\
\hline $4-6$ & $41(19.81)$ & $17(30.91)$ & $58(22.14)$ & $>0.05$ \\
\hline $7-9$ & $30(14.49)$ & $8(14.55)$ & $38(14.50)$ & $>0.05$ \\
\hline$>9$ & $59(28.50)$ & $20(36.36)$ & $79(30.15)$ & $>0.05$ \\
\hline Total & 207 (79.01) & 55 (20.99) & $262(100)$ & \\
\hline
\end{tabular}

difference between the groups $(p<0.05)$. According to our results, community pharmacists received more ADR reports from patients (12 (21.82\%)) than that of hospital pharmacists $(23(11.17 \%))$ with a significant difference between the groups $(p<0.05)$. Furthermore, $25(45.45 \%)$ community pharmacists and 135 (66.83\%) hospital pharmacists chose to report ADRs to SFDA, whereas 19 (34.55\%) community pharmacists chose to report ADRs to the Ministry of Health with significant differences between the groups $(p<0.05)$ (Table 2).

Pharmacists were asked about their first action when dealing with a patient with severe ADRs and the options were "contacted the physician," "report ADRs" and "direct the patient to an emergency room," "document the ADR in the patient's file," "recommend the patient to discontinue the drug with no further action," and "investigate if the ADR was known and ask the patient to contact the doctor." Some hospital and community pharmacists $(30.58 \%, 29.09 \%$, respectively) chose to direct the patient to an emergency room and the other community pharmacists (25.45\%) decided to ask the patient to contact the doctor. Hospital pharmacists $(8.25 \%)$ chose to ask the patient to contact the doctor with significant difference between the groups $(<0.05)$. Other hospital pharmacists (18.93\%) decided to investigate if the ADR was known, whereas only 9.09\% of the community pharmacists chose to do so (Figure 1).

With regard to the factors that may encourage pharmacists to report ADRs, community and hospital pharmacists (41(74.55\%), 125 (61.58\%), respectively) strongly agreed that serious ADRs encourage them to report, whereas $11(5.42 \%)$ hospital pharmacists were uncertain about the same as compared to community pharmacists $0(0.00 \%)$ with a significant difference $(p<0.05)$. The majority of the pharmacists were encouraged to report ADRs of new products 


\begin{tabular}{|c|c|c|c|c|c|c|c|c|}
\hline No. & Factors & $\begin{array}{l}\text { Type of } \\
\text { working } \\
\text { site }\end{array}$ & Yes (\%) & No $(\%)$ & $\begin{array}{l}\text { I do not } \\
\text { know (\%) }\end{array}$ & $\begin{array}{l}\text { No. of } \\
\text { respondents }\end{array}$ & $P$ value & \\
\hline \multirow{3}{*}{1} & \multirow{3}{*}{$\begin{array}{l}\text { Have you ever } \\
\text { reported any ADR? }\end{array}$} & $\mathrm{CP}$ & $9(16.36)$ & $46(83.64)$ & - & $55(20.91)$ & $<0.05$ & \\
\hline & & $\mathrm{HP}$ & $73(35.10)$ & $135(64.90)$ & - & $208(79.09)$ & $<0.05$ & \\
\hline & & Total & $82(31.18)$ & $181(68.82)$ & - & $263(100)$ & & \\
\hline \multirow{4}{*}{2} & \multirow{4}{*}{$\begin{array}{l}\text { Do you have ADR } \\
\text { reporting form at your } \\
\text { pharmacy? }\end{array}$} & $\mathrm{CP}$ & 6 (10.91) & 49 (89.09) & - & $55(20.91)$ & $<0.05$ & \\
\hline & & $\mathrm{HP}$ & 155 (74.52) & $53(25.48)$ & - & 208 (79.09) & $<0.05$ & \\
\hline & & Total & $161(61.22)$ & $102(38.78)$ & - & $263(100)$ & & \\
\hline & & & $\begin{array}{l}\text { I phone the } \\
\text { drug company }\end{array}$ & $\begin{array}{l}\text { I verbally } \\
\text { inform the } \\
\text { representative } \\
\text { of the drug } \\
\text { company on } \\
\text { routine visits }\end{array}$ & $\begin{array}{l}\text { I mail the } \\
\text { ADRs from via } \\
\text { internet }\end{array}$ & $\begin{array}{l}\text { I fill the adverse } \\
\text { drug reaction } \\
\text { reporting form }\end{array}$ & $\begin{array}{l}\text { No. of } \\
\text { respondents }\end{array}$ & $P$ value \\
\hline \multirow{4}{*}{3} & \multirow{3}{*}{$\begin{array}{l}\text { How do you report the } \\
\text { ADRs? (Select one } \\
\text { option) }\end{array}$} & $\mathrm{CP}$ & $5(11.36)^{*}$ & $12(27.27)^{*}$ & $6(13.64)$ & $21(47.73)^{*}$ & $44(18.26)$ & ${ }^{*}<0.05$ \\
\hline & & $\mathrm{HP}$ & $5(2.54)^{*}$ & $7(3.55)^{*}$ & $21(10.66)$ & $164(83.25)^{\star}$ & $197(81.74)$ & ${ }^{*}<0.05$ \\
\hline & & Total & $10(4.15)$ & $19(7.88)$ & $27(11.20)$ & $185(76.76)$ & $241(100)$ & \\
\hline & & & $\begin{array}{l}\text { More than } \\
\text { once a week }\end{array}$ & Once a month & $\begin{array}{c}\text { A few times a } \\
\text { year }\end{array}$ & Never & $\begin{array}{l}\text { No. of } \\
\text { respondents }\end{array}$ & $P$ value \\
\hline \multirow{4}{*}{4} & \multirow{3}{*}{$\begin{array}{l}\text { How often do the } \\
\text { patients report you } \\
\text { ADRs of medications? }\end{array}$} & $\mathrm{CP}$ & $12(21.82)^{\star}$ & $11(20.00)$ & $22(40.00)$ & 10 (18.18) & $55(21.07)$ & $*<0.05$ \\
\hline & & $\mathrm{HP}$ & $23(11.17)^{*}$ & $44(21.36)$ & $94(45.63)$ & $45(21.84)$ & 206 (78.93) & $*<0.05$ \\
\hline & & Total & 35 (13.41) & $55(21.07)$ & 116 (44.44) & $55(21.07)$ & $261(100)$ & \\
\hline & & & $\begin{array}{l}\text { The Ministry of } \\
\text { health (MOH). }\end{array}$ & $\begin{array}{l}\text { The Saudi } \\
\text { food and drug } \\
\text { administration }\end{array}$ & Drug company & Prescriber & $\begin{array}{l}\text { No. of } \\
\text { respondents }\end{array}$ & $P$ value \\
\hline \multirow{3}{*}{5} & \multirow{3}{*}{$\begin{array}{l}\text { To whom do you } \\
\text { report the ADRs? } \\
\text { (Select one option) }\end{array}$} & $\mathrm{CP}$ & $19(34.55)$ & $25(45.45)^{\star}$ & $4(7.27)$ & $7(12.73)$ & $55(21.40)$ & ${ }^{*}<0.05$ \\
\hline & & $\mathrm{HP}$ & $44(21.78)$ & $135(66.83)^{*}$ & $10(4.95)$ & $13(6.44)$ & $202(78.60)$ & $*<0.05$ \\
\hline & & Total & $63(24.51)$ & $160(62.26)$ & $14(5.45)$ & $20(7.78)$ & $257(100)$ & \\
\hline
\end{tabular}

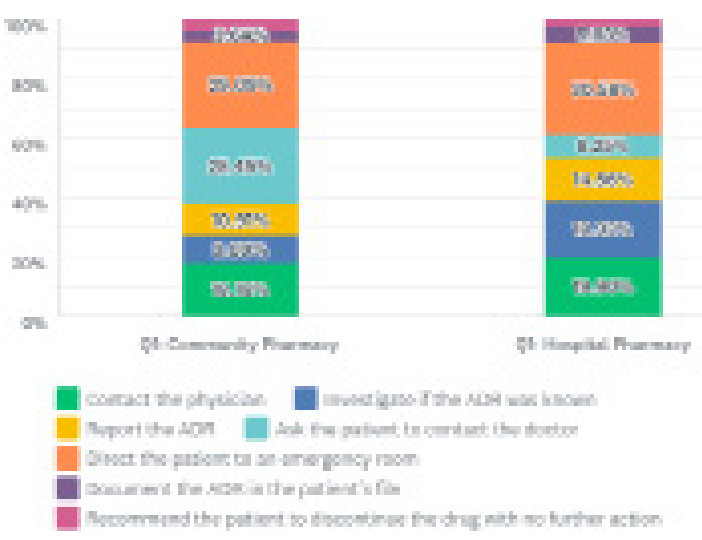

Figure 1: First actions that pharmacists perform when dealing with patients with severe adverse drug reactions (ADRs).

(29 (55.77\%)) of community pharmacists and 110 (53.92\%) of hospital pharmacists with no significant difference between groups ( $p>0.05$ ), unusual reactions encourage 27 (51.92\%) of community pharmacists and 107 (52.45\%) of hospital pharmacists with no significant difference. On the one hand, 26 (50\%) community pharmacists and 104 (50.49\%) hospital pharmacists strongly agreed that they were encouraged to report new ADRs that have not been reported earlier. On the other hand, 3 (5.77\%) community pharmacists strongly disagreed to report well-recognized ADRs for a particular drug as compared to $2(0.99 \%)$ hospital pharmacists, whereas $41(20.20 \%)$ of hospital pharmacists were uncertain about the same with a significant difference between groups $(p<0.05)$ (Table 3$)$.

Regarding factors that might discourage pharmacists from reporting ADRs, community and hospital pharmacists (19 (34.55\%) and 73 (35.96\%), respectively) agreed that the level of clinical knowledge makes it difficult to decide whether an ADR has occurred with no significant difference between the groups. Some hospital pharmacists $(37(18.32 \%))$ strongly agreed that uncertain association between the drug and the ADR discourage them from reporting the ADRs. In addition, $22(43.14 \%)$ community pharmacists agreed that one of the reasons that hinder them from reporting ADRs is that the ADR is too trivial to be reported, whereas only $44(21.67 \%)$ of the hospital pharmacists agreed to report such ADRs. While $76(37.44 \%)$ of hospital pharmacists were uncertain and $46(22.66 \%)$ of hospital pharmacists disagreed to report trivial ADRs showing 


\begin{tabular}{|c|c|c|c|c|c|c|c|c|c|}
\hline No. & Factors & $\begin{array}{l}\text { Type of } \\
\text { working } \\
\text { site }\end{array}$ & $\begin{array}{l}\text { Strongly } \\
\text { agree }\end{array}$ & Agree & Uncertain & Disagree & $\begin{array}{l}\text { Strongly } \\
\text { disagree }\end{array}$ & $\begin{array}{l}\text { No. of } \\
\text { respondents }\end{array}$ & $\begin{array}{l}P \\
\text { value }\end{array}$ \\
\hline \multirow[t]{3}{*}{1} & \multirow{3}{*}{$\begin{array}{l}\text { The reaction is of a } \\
\text { serious nature }\end{array}$} & $\mathrm{CP}$ & $41(74.55)$ & $12(21.82)$ & $0(0.00)$ & $0(0.00)$ & $2(3.64)^{*}$ & $55(21.32)$ & ${ }^{*}<0.05$ \\
\hline & & $\mathrm{HP}$ & 125 (61.58) & 60 (29.56) & $11(5.42)$ & $7(3.45)$ & $0(0.00)^{*}$ & $203(78.68)$ & $*<0.05$ \\
\hline & & Total & $166(64.34)$ & 72 (27.91) & $11(4.26)$ & $7(2.71)$ & $2(0.78)$ & $258(100)$ & \\
\hline \multirow[t]{3}{*}{2} & \multirow{3}{*}{$\begin{array}{l}\text { The reaction is } \\
\text { unusual }\end{array}$} & $\mathrm{CP}$ & $27(51.92)$ & $22(42.31)$ & $1(1.92)$ & $1(1.92)$ & $1(1.92)$ & $52(20.31)$ & $>0.05$ \\
\hline & & $\mathrm{HP}$ & $107(52.45)$ & 77 (37.75) & $14(6.86)$ & $4(1.96)$ & $2(0.98)$ & $204(79.69)$ & $>0.05$ \\
\hline & & Total & $134(52.34)$ & $99(38.67)$ & $15(5.86)$ & $5(1.95)$ & $3(1.17)$ & $256(100)$ & \\
\hline \multirow[t]{3}{*}{3} & \multirow{3}{*}{$\begin{array}{l}\text { The reaction is to a } \\
\text { new product }\end{array}$} & $\mathrm{CP}$ & $29(55.77)$ & $20(38.46)$ & $1(1.92)$ & $2(3.85)$ & $0(0.00)$ & $52(20.31)$ & $>0.05$ \\
\hline & & $\mathrm{HP}$ & $110(53.92)$ & $76(37.25)$ & $14(6.86)$ & $4(1.96)$ & $0(0.00)$ & 204 (79.69) & $>0.05$ \\
\hline & & Total & $139(54.30)$ & $96(37.50)$ & $15(5.86)$ & $6(2.34)$ & $0(0.00)$ & $256(100)$ & \\
\hline \multirow[t]{3}{*}{4} & \multirow{3}{*}{$\begin{array}{l}\text { Reaction not } \\
\text { reported before for a } \\
\text { particular drug }\end{array}$} & $\mathrm{CP}$ & $26(50.00)$ & 18 (34.62) & $6(11.54)$ & $1(1.92)$ & $1(1.92)^{*}$ & $52(20.16)$ & ${ }^{*}<0.05$ \\
\hline & & HP & $104(50.49)$ & 72 (34.95) & $21(10.19)$ & $9(4.37)$ & $0(0.00)^{*}$ & $206(79.84)$ & ${ }^{*}<0.05$ \\
\hline & & Total & $130(50.39)$ & $90(34.88)$ & $27(10.47)$ & $10(3.88)$ & $1(0.39)$ & 258 (100) & \\
\hline \multirow[t]{3}{*}{5} & \multirow{3}{*}{$\begin{array}{l}\text { Reaction is well } \\
\text { recognized for a } \\
\text { particular drug }\end{array}$} & $\mathrm{CP}$ & $12(23.08)$ & 20 (38.46) & $6(11.54)$ & $11(21.15)$ & $3(5.77)^{*}$ & $52(20.39)$ & ${ }^{*}<0.05$ \\
\hline & & HP & $51(25.12)$ & $84(41.38)$ & $41(20.20)$ & $25(12.32)$ & $2(0.99)^{*}$ & $203(79.61)$ & ${ }^{*}<0.05$ \\
\hline & & Total & $63(24.71)$ & $104(40.78)$ & 47 (18.43) & $36(14.12)$ & $5(1.96)$ & $255(100)$ & \\
\hline
\end{tabular}

significant difference between groups $(p<0.05)$. Onefourth of the community pharmacists $(13(25 \%))$ were uncertain of reporting ADRs as it usually generates extra work; 24 (11.82\%) of the hospital pharmacists responded as uncertain in reporting ADRs, whereas 39 (19.21\%) of hospital pharmacists disagreed about that reporting will generate extra work compared to $4(7.69 \%)$ of the community pharmacists, with significant difference between the groups $(p<0.05)$. As compared to hospital pharmacists (20 (9.80\%)), some of the community pharmacists (13 (25\%)) strongly agreed that the ADR form is not available when needed, with a significant difference $(p<0.05)$. Both community and hospital pharmacists (25 (48.08\%) and $88(43.14 \%)$, respectively) agreed that there is not enough information available from the patient with no significant difference between groups $(p>0.05)$. Compared to 65 (32.02\%) hospital pharmacists, 26 (50\%) community pharmacists disagreed about that lack of time which might be a discouraging factor for reporting of ADRs. About 26 (50\%) community pharmacists agreed that they do not know how to report ADRs as compared to 46 (22.55\%) of the hospital pharmacists, which was significantly different $(p<0.05)$ (Tables 4 and 5).

\section{DISCUSSION}

The pharmacists need to follow the processes of ADR to practice the reporting system; that is starting from the background knowledge until sending the ADR forms. In this study, the findings demonstrated that the majority of the community pharmacists do not have the ADR forms available in their pharmacy, which agrees with the results of previous studies. ${ }^{[6,10]}$ Hospital pharmacists did not suffer from this problem as it is a part of their work in the hospital. Most of the hospital pharmacists chose to report ADRs by filling the ADR form, whereas the rest decided to verbally inform the representative of the drug company on routine visits. According to community pharmacists, more number of patients come to report ADRs to them than that of hospital pharmacists, which shows the better working practice of community pharmacists. Hospital pharmacists were more aware of the person to whom they were supposed to report the ADRs; some chose to report to the Ministry of Health and other chose to report to the SFDA, which makes it clear that community pharmacists need more attention to increase their awareness regarding pharmacovigilance and ADR reporting system. This result agrees with the results of previous studies. ${ }^{[6,8]}$ Hospital pharmacists were more aware of the practice of reporting ADRs compared to hospital pharmacists. However, the report rate was very low for both of the groups, which also agrees with the results of previous studies. ${ }^{[9-11]}$ In this study, pharmacists were encouraged to report severe ADRs, but when asked about the initial action to be taken with a patient suffering from a severe ADR, then only a few responded that they would report serious ADRs. The majority of both community and hospital pharmacists tended to guide patients to an emergency room. Furthermore, some community pharmacists chose to ask the patient to contact the doctor unlike 


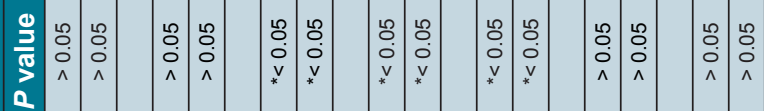

禺

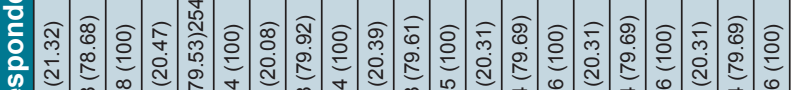

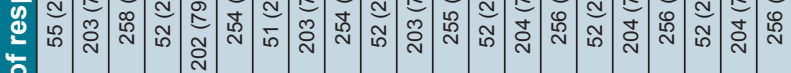

i

离

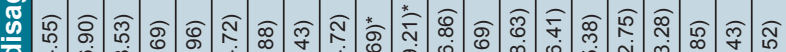
خ)

के

\&

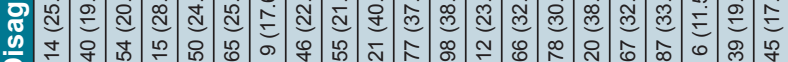

政

$\frac{1}{5}$

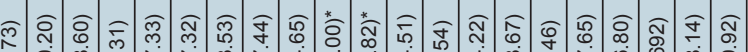

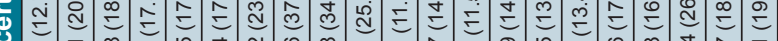
읍 응

일

ลื

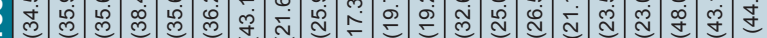

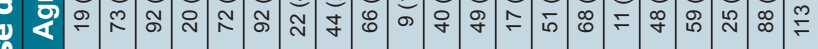

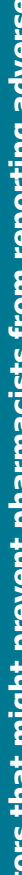

$\$$

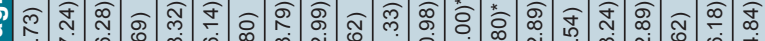

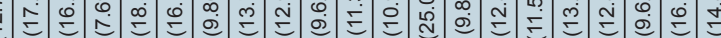
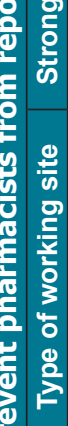

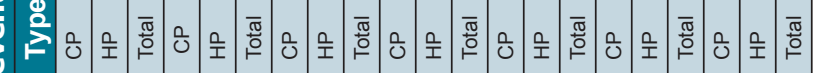

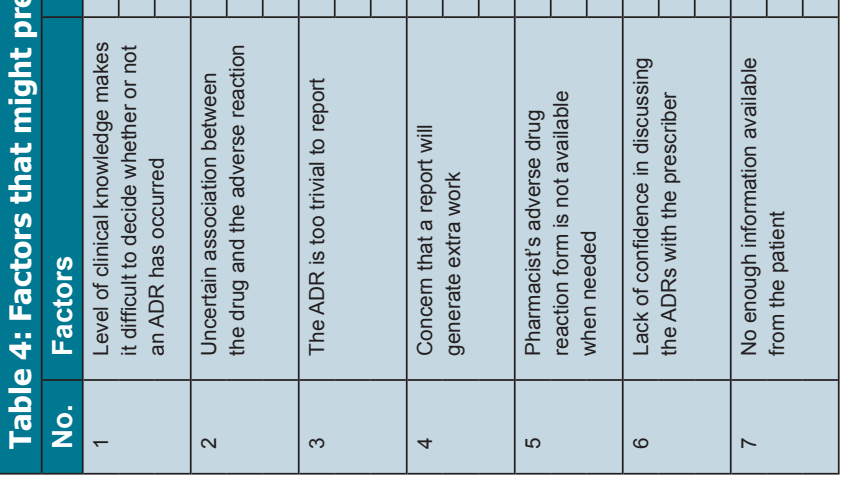

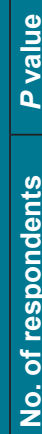

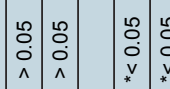

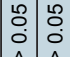

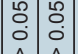

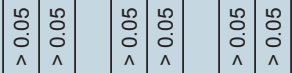

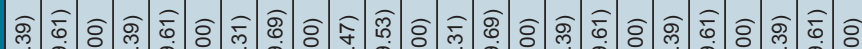

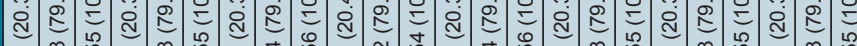

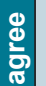

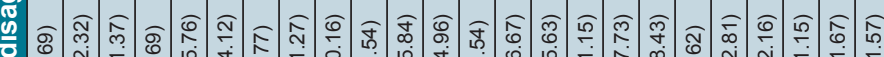

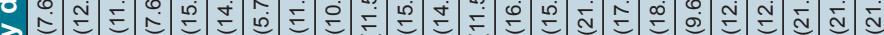

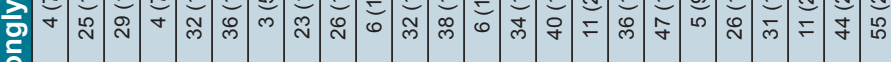

के

\&ँำ

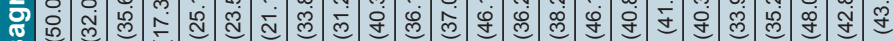

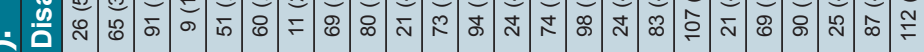

(1)

定

ส $\widehat{ } \widehat{\infty}$

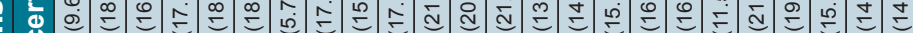
는

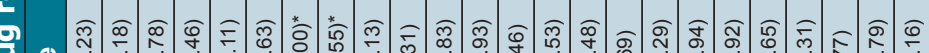

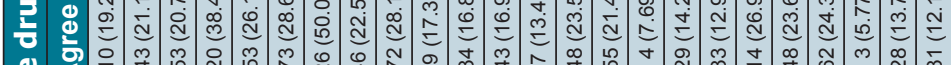

융

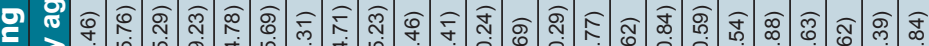
言 근 한 율 要

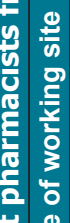

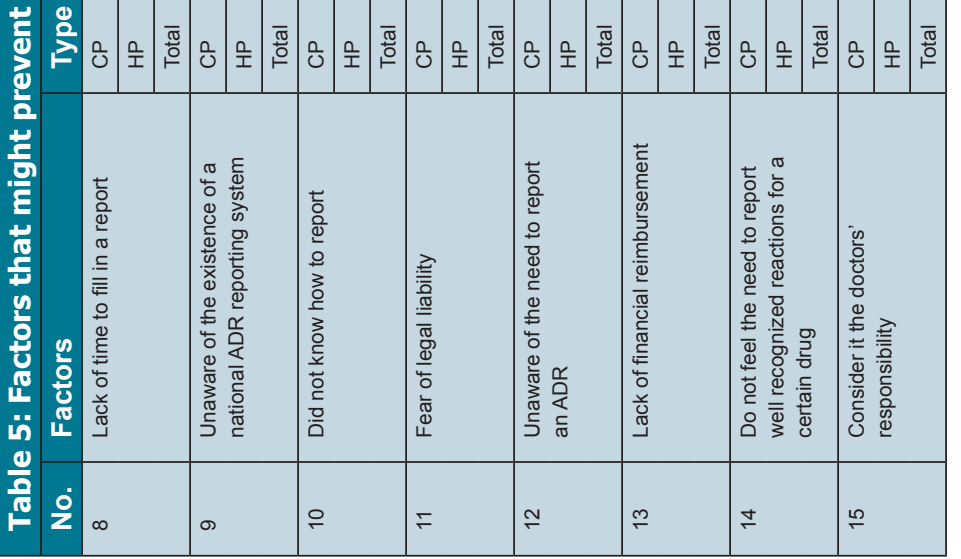


hospital pharmacists; this behavior was also seen in previous studies. ${ }^{[8,10]}$ In addition, both community and hospital pharmacists were encouraged to report unusual reactions, reaction to the new product and new responses to a specific drug that has not been stated before and they were unwilling to report wellknown ADRs, a finding that confirms the results of previous studies. ${ }^{[4,6]}$ Several factors found in this study discouraged community and hospital pharmacists from reporting ADRs, such as when the patient did not provide sufficient information because of which the pharmacist would be uncertain about the relationship between the ADR and the medication. The level of clinical knowledge also made it difficult to decide whether an ADR had occurred. Half of the community pharmacists participated in this study agreed that they did not know how to report ADRs similar to previous studies conducted inside and outside of Saudi Arabia. [6,8,9] This problem was found to be less with hospital pharmacists. Furthermore, community pharmacists agreed that the ADR might have been too trivial to be reported, which was found to be similar to the findings of previous studies; ${ }^{[6,8,9,12]}$ they stated that the ADRs were not significant to report and they are unwilling to report well-known ADRs. Some community pharmacists also strongly agreed that the ADR reporting form was not available when it needed, which indicates the low awareness of community pharmacists that the form was available online. ${ }^{[1]}$ Workload and lack of time were not barriers to reporting ADRs according to the result shown in this study, which is not similar to the outcome of previous studies. ${ }^{[6,10]}$ This study showed the persistent need for an educational program to enhance the awareness about the pharmacovigilance system, especially for community pharmacists. The drug regulatory body needs to increase attention and focus on targeting community pharmacists and continue attempts to hold educational campaigns and workshops for all healthcare providers. ${ }^{[13,14]}$ SFDA has developed a mobile application that provides the user with notification for any warnings and alerts, awareness messages regarding food, medications and medical devices in addition to a special section for pharmacovigilance in order to make the reporting process more accessible. This mobile app can ease the access to the electronic ADR form, obviating the need to go to the main page of the SFDA website and start a search within a site. ${ }^{[15]}$ Healthcare professionals in general and especially pharmacists need to be aware of this mobile application as it can play a role in increasing the report rate of ADRs.

\section{Study limitation}

We are aware of some limitations of this study. Part of the questionnaire was in an electronic form, which might have contributed to some bias and some paper questionnaires were not collected at the same time because some of the pharmacists were busy. Moreover, they might have felt forced to complete the survey or were not willing to reveal their practice deficiencies.

\section{CONCLUSION}

Hospital pharmacists have higher awareness regarding the practice of reporting ADRs and pharmacovigilance system compared to community pharmacists. Despite this, the reporting rate of ADRs for both community and hospital pharmacists was meager. The mobile application has eased out the reporting process.

\section{ACKNOWLEDGEMENT}

We wish to thank health research center in eastern region for distributing the questionnaire among hospitals

\section{CONFLICT OF INTEREST}

None.

\section{ABBREVIATIONS}

ADRs: Adverse Drug Reactions; FDA: Food and Drug Administration; SFDA: Saudi Food and Drug Authority; MOH: Ministry of Health; BSC: Bachelor of Science; SPSS: Statistical Package for the Social Sciences.

\section{ORCID ID}

Yousef Ahmed Alomi (D) https://orcid.org/0000-00031381-628X

\section{REFERENCES}

1. Alshammari TM, Alshakka M, Aljadhey H. Pharmacovigilance system in Saudi Arabia. Saudi Pharm J. 2017;25(3):299-305.

2. Zawahir S, Sultan RAA, Asmani MFM, Bushell MJA. Pharmacy students' knowledge and perceptions of adverse drug reactions and reporting. Pharmaceutical Journal of Sri Lanka. 2015;5:25-33.

3. Sales I, Aljadhey H, Albogami Y, Mahmoud MA. Public awareness and perception toward Adverse Drug Reactions reporting in Riyadh, Saudi Arabia. Saudi Pharm J. 2017;25(6):868-72.

4. Granas AG, Buajordet M, Stenberg-Nilsen H, Harg P, Horn AM. Pharmacists' attitudes towards the reporting of suspected adverse drug reactions in Norway. Pharmacoepidemiol Drug Saf. 2007;16(4):429-34. 


\section{Doughan, et al.: Pharmacist's Practice of Reporting ADRs}

5. Toklu HZ, Uysal MK. The knowledge and attitude of the Turkish community pharmacists toward pharmacovigilance in the Kadikoy district of Istanbul. Pharm World Sci. 2008;30(5):556-62.

6. Al-Hazmi N, Naylor IL. Attitude and Awareness of Adverse Drug Reaction Reporting by Health Professionals in Seven Hospitals in the Holy City of Makkah, Kingdom of Saudi Arabia. J Clin Trials. 2013;3:139.

7. Green CF, Mottram DR, Rowe PH, Pirmohamed M. Attitudes and knowledge of hospital pharmacists to adverse drug reaction reporting. Br J Clin Pharmacol. 2001;51(1):81-6.

8. Mahmoud MA, Alswaida Y, Alshammari T, Khan TM, Alrasheedy A, Hassali MA, et al. Community pharmacists' knowledge, behaviors and experiences about adverse drug reaction reporting in Saudi Arabia. Saudi Pharm J. 2014;22(5):411-8.

9. Suyagh M, Farah D, Abu FR. Pharmacist's knowledge, practice and attitudes toward pharmacovigilance and adverse drug reactions reporting process. Saudi Pharm J. 2015;23(2):147-53.

10. Salim M, Hussain N, Balasubramanian T, Lubab M, Nayana SA, et al. The Current Perspective of Community Pharmacists towards Pharmacovigilance. J Pharmacovigil. 2015;3:180.

11. Green CF, Mottram DR, Rowe PH, Pirmohamed M. Attitudes and knowledge of hospital pharmacists to adverse drug reaction reporting. Br J Clin Pharmacol. 2001;51(1):81-6.

12. Vessal G, Mardani Z, Mollai M. Knowledge, attitudes and perceptions of pharmacists to adverse drug reaction reporting in Iran. Pharm World Sci. 2009;31(2):183-7.

13. Reumerman M, Tichelaar J, Piersma B, Richir MC, Agtmael MAV. Urgent need to modernize pharmacovigilance education in healthcare curricula: review of the literature. Eur J Clin Pharmacol. 2018;1-14.

14. Abdel-Latif MMM, Abdel-Wahab BA. Knowledge and awareness of adverse drug reactions and pharmacovigilance practices among healthcare professionals in Al-Madinah Al-Munawwarah, Kingdom of Saudi Arabia. Saudi Pharm J. 2015;23(2):154-61.

15. Saudi Food and Drug Athurity applications and tables. [cited 2019 Jan 6]. Available from: https://www.sfda.gov.sa/ar/Pages/smartapps.aspx

Cite this article as: Al Doughan FF. Pharmacist's Practice of Reporting of Adverse Drug Reactions in Saudi Arabia. Int J Pharmacol. Clin. Sci. 2019;8(1):86-93. 